\title{
Highlighting and Interpreting Current Empirical Facets of the Greek Educational Pathogeny: \\ A Sociological Approach
}

\author{
Christos Goulas \\ Labour Institute (INE GSEE); \\ Centre for Educational Policy Development of the General Confederation of Greek Labour
} (KANEP GSEE)

Benaki Em. Str 71A, 106 81, Athens, Greece

Tel: 30-210-332-7710 E-mail: goulas@inegsee.gr

Nikos Fotopoulos (Corresponding author)

Department of Social \& Education Policy, University of Peloponnese;

Centre for Educational Policy Development of the General Confederation of Greek Labour (KANEP GSEE)

Septemvriou 3rd, 36, 104 32, Athens, Greece

Tel: 30-210-521-8707 E-mail: nikfot@otenet.gr \& nfotop@uop.gr

Polina Fatourou

Centre for Educational Policy Development of the General Confederation of Greek Labour (KANEP GSEE)

Septemvriou 3rd, 36, 104 32, Athens, Greece

Tel: 30-210-521-8746 E-mail: pfatourou@kanep-gsee.gr

Received: May 6, 2021 Accepted: May 30, $2021 \quad$ Published: June 11, 2021

doi:10.5296/jei.v7i1.18621ＵRL: https://doi.org/10.5296/jei.v7i1.18621

\section{Abstract}

This paper aims at highlighting and interpreting current empirical facets of the Greek 
educational pathogeny through a sociological approach. Especially, the paper tries to investigate the relationship between education and employment in modern Greece based on the annual statistical report of KANEP/GSEE, choosing both selected facets and sociologically interpreted issues such as public and private expenditure, trends on specialties, outcomes of initial training teacher's profile etc. According to this data, the main political challenge is based on both the decrease of public expenditure and the maintenance of significantly high levels of household expenditure. Additionally, current trends, such as «brain drain» or migration of highly educated people, prove that Greek public universities' learning outcomes remain competitive and effective through the framework of a global labour market, notwithstanding the harsh critique blaming them for «statism» and mismatching with the labour needs.

Keywords: Greek educational system, Pathogeny, Public universities, Teachers

\section{Introduction}

The Centre for Educational Policy Development of the General Confederation of Greek Labour-which has been preparing reports on education at annual basis for the last decade - released the data of its Annual Report on education at the beginning of 2021. Essentially, this report can be used as a tool that monitors the key indicators and the trends of education, which reflects the evolution and progress of the country's education system in direct correlation with the European reference framework. This year's report highlighted, inter alia, the connection between education and employment, putting emphasis on higher education and its outputs in key figures. According to the main findings of the Report, especially during the last decade in the country, long-standing problems of the Greek education system have shown a further aggravation, ranking the country-in a crucial number of indicators - in an extremely difficult position compared to the European average and the other Member States of the EU-28. Additionally, the phenomenon of "shadow education" (Bray, 2011) is still omni-present, as a structural feature, through a reality where the public expenditures are decreasing drastically. Unfortunately, symptoms such as a "brain drain", "brain waste", "the increasing trend of privatization" are gaining more space within the public sphere in a period where Greek society tries to alleviate the tough consequences of "memorandum" policies which have been in place since 2008 (Chalari, 2017). With no doubt this makes the dimension of public policies (Hanushek \& Kain, 1972; John, 2013) more significant thanks to the crucial role that public education, especially public universities, could play for growth and public cohesion. Nevertheless, we need to consider the issue of the Greek case not as an exclusively unique phenomenon, but as a part of a global strategy through the spectrum of globalization (Docquier \& Rapoport, 2012), where education policy is forced to follow the dominant trends, i.e., the rules, pressure, and control of the global market economy.

\section{Greek Education System and Expenditure: Current Facets and Dimensions of the Greek Pathogeny}

In particular, based on the information in the report, there are two findings of major importance concerning the public and private expenditure for education, i.e., the amounts 
paid by the state budget for education as well as the money that families or, more precisely, households spend on educating their members. More specifically, in relation to the first dimension, the general government expenditure on education in Greece over time remains well below the European average $(8.3 \%$ as against $10.3 \%$, respectively), while both the Public Investment Programme and the Regular Budget of the Ministry of Education marginally cover the operational needs of the system (KANEP, 2020). Undoubtedly, the long-term reduction has very serious consequences at all levels and particularly at those areas of the system that are of vital importance for social cohesion and the country's developmental perspective. In support of this statement, it should be noted that the public spending on education, especially during the period 2008-2019 (Table 1), recorded unprecedented low levels, ranking the country in the 27th position among EU-28 Members States in 2019 (Table 2).

Table 1. General government expenditure on Education (COFOG99) in EU-28 and Greece (2001-2019) (in million euros)

\begin{tabular}{|l|l|l|}
\hline Year & EU-28 & Greece \\
\hline 2001 & $488,832.2$ & $5,643.0$ \\
\hline 2002 & $525,104.8$ & $6,395.0$ \\
\hline 2003 & $537,652.7$ & $7,612.0$ \\
\hline 2004 & $551,977.0$ & $7,954.0$ \\
\hline 2005 & $576,099.3$ & $8,389.0$ \\
\hline 2006 & $603,955.7$ & $7,947.0$ \\
\hline 2007 & $629,775.2$ & $8,357.0$ \\
\hline 2008 & $641,381.2$ & $9,130.0$ \\
\hline 2009 & $643,988.8$ & $9,810.0$ \\
\hline 2010 & $669,607.8$ & $9,280.0$ \\
\hline 2011 & $668,271.6$ & $9,182.0$ \\
\hline 2012 & $673,056.4$ & $8,632.0$ \\
\hline 2013 & $674,370.5$ & $8,086.0$ \\
\hline 2014 & $695,885.5$ & $7,659.0$ \\
\hline 2015 & $721,410.5$ & $7,313.0$ \\
\hline 2016 & $713,784.2$ & $7,007.0$ \\
\hline 2017 & $725,641.2$ & $6,883.0$ \\
\hline 2018 & $747,151.8$ & $7,362.0$ \\
\hline 2019 & $777,070.0$ & $7,247.0$ \\
\hline
\end{tabular}

Source: Eurostat-General government expenditure by function (COFOG) [gov_10a_exp] (extracted on 06/04/2021). 
Table 2. General government expenditure on education in EU-28 member-states (2019)

\begin{tabular}{|c|c|c|}
\hline Countries & Million euros & $\%$ of Total general government expenditure \\
\hline European Union-28 countries (2013-2020) & $777,070.0$ & 10.3 \\
\hline Estonia & $1,698.2$ & 15.5 \\
\hline Latvia & $1,755.9$ & 15.0 \\
\hline Malta & 706.8 & 14.2 \\
\hline Sweden & $32,907.1$ & 14.1 \\
\hline Cyprus & $1,193.3$ & 13.4 \\
\hline Lithuania & $2,250.2$ & 13.3 \\
\hline Ireland & $11,160.8$ & 12.8 \\
\hline Denmark & $19,622.7$ & 12.7 \\
\hline Slovenia & $2,639.5$ & 12.6 \\
\hline Poland & $26,731.7$ & 12.0 \\
\hline United Kingdom & $122,819.2$ & 11.9 \\
\hline Czechia & $10,954.0$ & 11.8 \\
\hline Belgium & $29,323.5$ & 11.8 \\
\hline Netherlands & $40,154.0$ & 11.8 \\
\hline Luxembourg & $2,957.7$ & 11.0 \\
\hline Bulgaria & $2,375.8$ & 10.7 \\
\hline Finland & $13,507.0$ & 10.6 \\
\hline Portugal & $9,409.9$ & 10.3 \\
\hline Hungary & $6,874.7$ & 10.3 \\
\hline Croatia & $2,608.4$ & 10.2 \\
\hline Romania & $8,134.4$ & 10.1 \\
\hline Austria & $18,970.1$ & 9.9 \\
\hline Slovakia & $3,951.1$ & 9.9 \\
\hline Germany & $149,201.0$ & 9.6 \\
\hline Spain & $49,817.0$ & 9.5 \\
\hline France & $128,092.0$ & 9.5 \\
\hline Greece & $7,247.0$ & 8.3 \\
\hline Italy & $70,006.9$ & 8.0 \\
\hline
\end{tabular}

Note: The table displays General government expenditure on code COFOG99 Education, in millions of euros $\left(1^{\text {st }}\right.$ column $)$ and as a percentage of Total General government expenditure $\left(2^{\text {nd }}\right.$ column). Countries are sorted by the percentage of expenditure on education.

Source: Eurostat-General government expenditure by function (COFOG) [gov_10a_exp] (extracted on 06/04/2021). 


\section{Macrothink Mnstitutem}

While the underfunding of the public education system emerges as a chronic "pathogeny", private expenditure on education, i.e., household expenditure, appears to be systematically and significantly higher than the European average $(2.1 \%$ as against $1.2 \%$ respectively) (Tables 3 and 4). These apply to out-of-school support for the preparation of students (secondary education) or expenditure on household members' studying in a different city from the household's place of residence (mainly higher education), bringing the country to the 3rd position among the 28 EU Member States with higher private spending (Table 5). Indicatively, the amount spent by Greek households on education for the year 2019 amounts to 2 billion and 905 million euros, accounting for about $2.1 \%$ of their total consumption expenditure.

Table 3. Percent distribution of final consumption expenditure of households by consumption purpose (COICOP 3 digit) in EU-28 and Greece (2019) (\%)

\begin{tabular}{|l|l|l|}
\hline Consumption purpose (COICOP) & European Union-28 countries (2013-2020) & Greece \\
\hline Total & 100.0 & 100.0 \\
\hline Food and non-alcoholic beverages & 12.1 & 15.2 \\
\hline Alcoholic beverages, tobacco and narcotics & 3.9 & 4.4 \\
\hline Clothing and footwear & 4.7 & 4.2 \\
\hline Housing, water, electricity, gas and other fuels & 23.9 & 19.1 \\
\hline $\begin{array}{l}\text { Furnishings, household equipment } \\
\text { and routine household maintenance }\end{array}$ & 5.4 & 2.7 \\
\hline Health & 3.9 & 4.2 \\
\hline Transport & 13.3 & 12.9 \\
\hline Communications & 2.2 & 3.9 \\
\hline Recreation and culture & 9.1 & 5.9 \\
\hline Education & 1.2 & 2.1 \\
\hline Restaurants and hotels & 8.9 & 17.8 \\
\hline Miscellaneous goods and services & 11.4 & 7.5 \\
\hline
\end{tabular}

Source: Eurostat - Final consumption expenditure of households by consumption purpose (COICOP 3 digit) [nama_10_co3_p3] (extracted on 06/04/2021). 
Table 4. Final consumption expenditure of households on Education (COICOP 3 digit) as a percentage of their Total Final consumption expenditure in EU-28 and Greece (2001-2019) $(\%)$

\begin{tabular}{|l|l|l|}
\hline Year & EU-28 & Greece \\
\hline 2001 & 0.5 & 1.0 \\
\hline 2002 & 0.5 & 1.2 \\
\hline 2003 & 0.5 & 1.4 \\
\hline 2004 & 0.5 & 1.4 \\
\hline 2005 & 0.5 & 1.6 \\
\hline 2006 & 0.5 & 1.6 \\
\hline 2007 & 0.5 & 1.6 \\
\hline 2008 & 0.5 & 1.6 \\
\hline 2009 & 0.6 & 1.7 \\
\hline 2010 & 0.6 & 1.7 \\
\hline 2011 & 0.6 & 1.7 \\
\hline 2012 & 0.6 & 1.6 \\
\hline 2013 & 0.6 & 1.5 \\
\hline 2014 & 0.6 & 1.6 \\
\hline 2015 & 0.6 & 1.5 \\
\hline 2016 & 0.7 & 1.4 \\
\hline 2017 & 0.6 & 1.5 \\
\hline 2018 & 0.6 & 1.5 \\
\hline 2019 & 0.6 & 1.6 \\
\hline & & \\
\hline
\end{tabular}

Source: Eurostat-Final consumption expenditure of households by consumption purpose (COICOP 3 digit) [nama_10_co3_p3] (extracted on 06/04/2021). 
Table 5. Final consumption expenditure of households on education in EU-28 member-states (2019)

\begin{tabular}{|l|l|l|}
\hline Countries & Million euros & $\begin{array}{l}\text { \% of Total consumption } \\
\text { expenditure of households }\end{array}$ \\
\hline European Union-28 countries (2013-2020) & $104,618.1$ & 1.2 \\
\hline Cyprus & 474.3 & 3.0 \\
\hline United Kingdom & $37,143.0$ & 2.4 \\
\hline Greece & $2,905.6$ & 2.1 \\
\hline Malta & 145.8 & 2.0 \\
\hline Ireland & $1,804.8$ & 1.8 \\
\hline Hungary & $1,254.4$ & 1.7 \\
\hline Latvia & 295.0 & 1.6 \\
\hline Spain & $11,417.0$ & 1.5 \\
\hline Portugal & $2,241.1$ & 1.5 \\
\hline Slovakia & 779.1 & 1.5 \\
\hline Slovenia & 331.8 & 1.3 \\
\hline Romania & $1,666.8$ & 1.2 \\
\hline Bulgaria & 407.3 & 1.1 \\
\hline Poland & $3,046.2$ & 1.0 \\
\hline Austria & $1,988.4$ & 1.0 \\
\hline Germany & $15,844.0$ & 0.9 \\
\hline Luxembourg & 191.6 & 0.9 \\
\hline Italy & $9,919.5$ & 0.9 \\
\hline Croatia & 357.8 & 0.9 \\
\hline Denmark & $1,189.6$ & 0.8 \\
\hline Netherlands & $2,340.0$ & 0.7 \\
\hline Czechia & 572.3 & 0.5 \\
\hline Estonia & 71.0 & 0.5 \\
\hline Lithuania & 146.8 & 0.5 \\
\hline France & $6,174.0$ & 0.5 \\
\hline Finland & 492.0 & 0.4 \\
\hline Belgium & 918.5 & 0.4 \\
\hline Sweden & 633.2 & 0.3 \\
\hline & & \\
\hline
\end{tabular}

Note. The table displays final consumption expenditure of households on code COICOP Education, in millions of euros ( $1^{\text {st }}$ column) and as a percentage of Total Final consumption expenditure ( $2^{\text {nd }}$ column). Countries are sorted by the percentage of expenditure on Education Source: Eurostat-Final consumption expenditure of households by consumption purpose (COICOP 3 digit) [nama_10_co3_p3] (extracted on 06/04/2021). 


\section{Greek Public Universities and Their Role in Labour Market}

The findings in the Report on Education are multiple and, in several cases, interrelated, highlighting the diachronic weaknesses in the Greek education system. Overall and in the longer run, there is a further weakening of the quality of "inputs" (funding, educational staff, adequacy and quality of infrastructure-equipment, curricula, etc.), resulting in a corresponding reduction in the quality of "outputs" (learning-educational outcomes). Apart from this combination of the two phenomena, it is very important to spot other factors that lead to increasing social and educational inequalities (Tsakloglou \& Cholezas, 2005), as well as the recycling of long-term weaknesses that reproduce the same pathogenies.

To understand deeply the function of the Greek pathogeny we must take into our consideration not only the economic dimension but the cultural background both for each family or individual separately and for society as a structured whole. With no doubt via this perspective, we can approach the issue of education holistically, highlighting cultural, social or historical dimensions that can shed light upon issues such as inequalities, educational choices, occupational trajectories etc. (Mills \& Gale, 2007). For instance, in conjunction with the findings outlined above, it is confirmed that the cost of state underfunding in education is essentially transferred onto the Greek families' expenditures. Those families continue to invest in their children's (Kassotakis \& Verdis, 2013) education despite the "mutations" that the traditional routes of graduates towards the labour market have undergone. Consequently, despite being aware of the difficulties involved, and under extremely adverse conditions, the main focus of citizens remains the much-needed access to the labour market (Liagouras, Protogerou, \& Caloghirou, 2003) anticipating better wages, smooth professional development, including guaranteeing job security in a labour market primarily dominated by underpaid and broadly low-quality employment. Obviously, the economic, social and psychological price respectively is extremely high, since - as the figures show - in the case of higher education graduates aged 25-39 being unemployed, Greece ranks 1st among the countries of the EU (19.9\%) (Table 6). 
Table 6. Unemployment rates by age and occupational attainment of persons aged 25-39 in EU-28 member-states (2018)

\begin{tabular}{|c|c|c|c|c|}
\hline & \multicolumn{2}{|c|}{$\begin{array}{l}\text { Unemployment rate of persons } \\
\text { aged 25-39 with tertiary education } \\
\text { attainment (ISCED 5-8) }\end{array}$} & \multicolumn{2}{|c|}{$\begin{array}{l}\text { Youth long-term unemployment } \\
\text { rate (12 months or longer) } \\
\text { of persons aged } 15-29\end{array}$} \\
\hline & Rank position & $\%$ & Rank position & $\%$ \\
\hline $\begin{array}{l}\text { European Union } \\
-28 \text { countries }(2013-2020)\end{array}$ & & 4.8 & & 3.6 \\
\hline Greece & 1 & 19.9 & 1 & 19.6 \\
\hline Spain & 2 & 10.5 & 3 & 6.9 \\
\hline Italy & 3 & 9.9 & 2 & 12.7 \\
\hline Croatia & 4 & 8.7 & 5 & 4.7 \\
\hline Cyprus & 5 & 8.6 & 11 & 2.9 \\
\hline Denmark & 6 & 5.9 & 23 & 1.0 \\
\hline France & 6 & 5.9 & 5 & 4.7 \\
\hline Portugal & 8 & 5.7 & 10 & 3.0 \\
\hline Luxembourg & 9 & 5.2 & 21 & 1.1 \\
\hline Slovenia & 9 & 5.2 & 16 & 1.8 \\
\hline Latvia & 11 & 4.7 & 11 & 2.9 \\
\hline Finland & 12 & 4.5 & 23 & 1.0 \\
\hline Sweden & 13 & 4.2 & 23 & 1.0 \\
\hline Slovakia & 14 & 4.0 & 4 & 5.7 \\
\hline Belgium & 15 & 3.8 & 9 & 3.6 \\
\hline Ireland & 15 & 3.8 & 13 & 2.5 \\
\hline Estonia & 17 & 3.4 & 27 & 0.8 \\
\hline Austria & 18 & 3.3 & 20 & 1.2 \\
\hline Bulgaria & 19 & 2.9 & 7 & 4.3 \\
\hline Germany & 20 & 2.5 & 18 & 1.4 \\
\hline Lithuania & 20 & 2.5 & 21 & 1.1 \\
\hline Poland & 22 & 2.4 & 17 & 1.5 \\
\hline Romania & 23 & 2.3 & 7 & 4.3 \\
\hline Netherlands & 24 & 2.1 & 28 & 0.7 \\
\hline United Kingdom & 24 & 2.1 & 18 & 1.4 \\
\hline Hungary & 26 & 1.6 & 15 & 2.0 \\
\hline Malta & 26 & 1.6 & 14 & 2.2 \\
\hline Czechia & 28 & 1.4 & 26 & 0.9 \\
\hline
\end{tabular}

Note. Countries are sorted by the unemployment rate of persons aged 25-39 with tertiary education attainment (ISCED 5-8).

Source: (a) Eurostat-Unemployment rates by sex, age and educational attainment level (\%) [1fsa_urgaed] (extracted on 06/04/2021); (b) Youth long-term unemployment rate (12 months or longer) by sex and age [yth_empl_120] (extracted on 08/04/2021). 
The picture is similar as regards the rate of youth long-term unemployed (up to the age of 29), scoring $19.6 \%$ (Table 6). However, this finding also relates to another negative aspect of our system's "outputs", since our country ranks 3rd in the EU-28, with a rate of $33.9 \%$, in terms of "vertical education-job" qualification and skill mismatch (also known as over-education) for working graduates from higher education, indicating that their job position falls short of their educational attainment (Table 8). This is a problematic phenomenon which has been significantly growing in the time of crisis (2010-2018) (Table 7).

Table 7. Vertical mismatch rate (ISCO08) of employed (aged 15-64) with tertiary education attainment (ISCED 5-8) in EU-28 and Greece (2001-2019) (\%)

\begin{tabular}{|c|c|c|}
\hline Year & Greece & EU-28 \\
\hline 2001 & 21.3 & 20.5 \\
\hline 2002 & 21.0 & 21.0 \\
\hline 2003 & 22.1 & 20.8 \\
\hline 2004 & 21.6 & 20.9 \\
\hline 2005 & 21.5 & 21.5 \\
\hline 2006 & 21.1 & 21.5 \\
\hline 2007 & 21.2 & 21.6 \\
\hline 2008 & 22.1 & 21.6 \\
\hline 2009 & 22.6 & 21.5 \\
\hline 2010 & 22.1 & 21.8 \\
\hline 2011 & 26.0 & 21.1 \\
\hline 2012 & 26.5 & 22.0 \\
\hline 2013 & 27.8 & 22.3 \\
\hline 2014 & 29.2 & 22.9 \\
\hline 2015 & 3.3 & 23.1 \\
\hline 2016 & 32.0 & 23.1 \\
\hline 2017 & 33.4 & 23.4 \\
\hline 2018 & 33.9 & 23.4 \\
\hline
\end{tabular}

Source: Eurostat-Employment by sex, occupation and educational attainment level (1 000$)$ [1fsa_egised] (KANEP/GSEE, 2019). 


\section{Macrothink}

Journal of Educational Issues

ISSN 2377-2263

2021, Vol. 7, No. 1

Table 8. Vertical mismatch rate (ISCO08) of employed (aged 15-64) with tertiary education attainment (ISCED 5-8) in EU-28 member-states (2018) (\%)

\begin{tabular}{|l|l|}
\hline Countries & $\%$ \\
\hline European Union-28 countries (2013-2020) & 23.4 \\
\hline Spain & 37.6 \\
\hline Greece & 33.9 \\
\hline Cyprus & 35.6 \\
\hline Sweden & 28.7 \\
\hline Ireland & 30.1 \\
\hline Latvia & 21.9 \\
\hline France & 22.7 \\
\hline Slovakia & 24.5 \\
\hline Estonia & 22.6 \\
\hline Belgium & 20.7 \\
\hline Bulgaria & 24.3 \\
\hline United Kingdom & 26.0 \\
\hline Poland & 20.5 \\
\hline Austria & 16.8 \\
\hline Malta & 18.6 \\
\hline Finland & 19.4 \\
\hline Germany & 19.4 \\
\hline Lithuania & 23.0 \\
\hline Slovenia & 17.5 \\
\hline Italy & 21.1 \\
\hline Romania & 20.0 \\
\hline Hungary & 15.4 \\
\hline Denmark & 16.2 \\
\hline Netherlands & 18.0 \\
\hline Croatia & \\
\hline Czechia & 15.2 \\
\hline Portugal & 15.1 \\
\hline Luxembourg & 28.5 \\
\hline
\end{tabular}

Note. Countries are sorted by the percentage value.

Source: Eurostat-Employment by sex, occupation and educational attainment level (1 000$)$ [1fsa_egised] (KANEP/GSEE, 2019). 
Regarding the distribution of undergraduate students by field of study, we observe that the students' preferences and, at the same time, the development of the map of higher education in Greece follow the general trends formed in the EU-28 with slight, but interesting, variations. The findings of the comparative analysis of student distributions by subject area in Greece and Europe will categorically preclude the "historical" argument of the alleged direction of Greek higher education institutions towards the production of "graduate candidates for civil servant jobs". Indeed, a careful reader will notice that the most significant difference in distribution rates concerns the category of engineering, manufacturing, and construction, which appears to be preferred by a proportion of students in Greece amounting to $23.6 \%$ as against $14.9 \%$ in the countries of the European Union $(+8.6 \%)$ (Table 9). Conversely, the biggest shortfalls do not relate to some alleged "civil servants' schools" but to the relative intense absence of students in productive sectors directly linked to the quality of life and the upgrading of the human resources: In Greece there are significantly fewer students in the fields of health and welfare services (10.6\% in EU-28 as against $6.6 \%$ in Greece), education ( $7.2 \%$ in EU-28 as against $4.3 \%$ in Greece) and studies focusing on service provision ( $4.0 \%$ in EU-28, while only $2.8 \%$ of the student population in Greece).

In other words - and for the sake of clarity and ease of comprehension of the above comparisons - the distribution of the student population by subject area confirms the tendency of students to opt for development studies with a focus on industrial production and infrastructure investments rather than the field of Information and Communication Technologies, which is lagging behind the European average (5.4\% in the EU-28, while 3.2\% in Greece). In addition, Greek levels for science and technology education volume are the same as in the EU-28. Those studies let graduates enter the labour market and engage in production activities without the need for public sector involvement. Specifically, according to the table describing the distribution of the student population attending higher education (undergraduate studies-ISCED 6) in Greece, we can see rates tantamount to European averages in fields of study, such as "business, administration and law", "natural sciences, mathematics and statistics", but also in "arts and humanities" or "social sciences, journalism and information". In other words, Greece-despite the high unemployment rate among tertiary education graduates-does not seem to differ from other European countries regarding the kind of "outputs" produced by its universities.

The present finding of KANEP GSEE's research has strongly refuted the ideologically stubborn myth that the Greek university constitutes a mechanism for the production of civil servants. This argument is not based on any measurable data, but instead on copy-and-paste findings and conclusions which have not been valid for decades. This assessment is clearly biased and lacks the capacity to be widely interpreted, since the subjects and scientific fields of study in Greek higher education are fully compatible and coordinated with what is provided and implemented in the EU Member States. 
Table 9. Percent distribution of students enrolled in bachelor's or equivalent level (ISCED 6) by field of study (ISCEDF13) in EU-28 and Greece (2018) (\%)

\begin{tabular}{|l|l|l|}
\hline ISCEDF13 & European Union-28 countries (2013-2020) & Greece \\
\hline Total & 100.0 & 100.0 \\
\hline Education & 7.2 & 4.3 \\
\hline Arts and humanities & 13.8 & 13.8 \\
\hline Social sciences, journalism and information & 11.3 & 12.2 \\
\hline Business, administration and law & 20.9 & 20.2 \\
\hline Natural sciences, mathematics and statistics & 8.9 & 8.9 \\
\hline Information and Communication Technologies & 5.4 & 3.3 \\
\hline Engineering, manufacturing and construction & 14.9 & 23.6 \\
\hline Agriculture, forestry, fisheries and veterinary & 1.7 & 4.4 \\
\hline Health and welfare & 10.6 & 6.6 \\
\hline Services & 4.0 & 2.8 \\
\hline
\end{tabular}

Source: Eurostat - Pupils and students enrolled by education level, sex and field of education [educ_uoe_enra03] (extracted on 06/04/2021).

Why are the skills corresponding to Greek degrees considered inadequate in the domestic labour market, while at the same time they are recognised, transferred, harnessed, and remunerated satisfactorily abroad? What is exactly the condition that reduces the validity of qualifications? Why is Greek graduates' unemployment directly linked to the migration issue of "brain drain" and the mobility of highly educated labour force to other places of the world? (Labrianidis \& Vogiatzis, 2013). Why in Greece university degrees do not have the expected value, while in many foreign countries they are in high demand? Is this situation associated with poor system management depreciating the seriousness and value of higher education graduates fleeing abroad?

Obviously, the debate on de-skilling is part of a broader attempt to devalue the qualifications of Greek graduates, since certain employer interest groups, increasing the labour costs, seek to exploit highly qualified personnel (levels 6,7 and 8 in the National [NQF] and the European Qualifications Framework (EQF]), but with salaries corresponding to low and medium qualifications (levels 3,4 and 5). After all, the tendency of the Greeks with the highest levels of education and skills to emigrate and, most importantly, to pursue successful career paths abroad is the best evidence that this does occur because of the quality of studies offered by Greek universities. Is the public education system solely liable for the domestic unemployment issue? Or the liability lies with the ineffective policies that cannot redeploy the production model of the country?

This illustrates, in conjunction with other findings related to the "vertical skill mismatch" (Allegro \& Giambalvo, 2020), that Greece does not there fall short of highly skilled 
workforce. On the contrary, once again, a necessary change within the production model is necessary, something requiring innovation and high-quality job creation with remuneration that meets our scientists' qualifications rather than push them to seek a better life abroad.

\section{Shift towards Non-formal Education or University Upgrading?}

According to an additional primary research project carried out by KANEP GSEE in 2020 (Goulas, Fotopoulos, 2021) on the transition of graduates of Vocational Training Institutes (IEK graduates) to the labour market, there is an increased participation of higher education graduates in initial training courses. Specifically, 9.2\% describe themselves as graduates of Technological Educational Institutes or Technical and Vocational Education Centres (TEI/KATEE), $9.9 \%$ as university graduates (AEI) and $4.8 \%$ as Master and $\mathrm{PhD}$ holders (Table 10). Such a tendency may be originally interpreted in the light of the weak link between higher education and employment. However, such an approach is unilateral and rather narrow, as the real issue is not driving young people away from higher education, which - as highlighted above - is compatible to the European standards in relation to the subjects, specialties, and fields of science. Conversely, in an era of high demand for highly qualified labour, it is particularly crucial to develop the role of universities, but also to strengthen their competitiveness and efficiency in the domestic and international labour market.

Table 10. Percent distribution of graduates of Vocational Training Institutes (IEK graduates) by educational level attainment in Greece $(2012,2020)(\%)$

\begin{tabular}{|l|r|r|}
\hline Educational level attainment & 2012 & 2020 \\
\hline 3 years Gymnasio & 0.8 & 46.4 \\
\hline 6 years Gymnasio, Lyceum & 66.4 & 11.5 \\
\hline Technical-Professional School (TEE/EPAL/EPAS) & 8.7 & 18.0 \\
\hline Institute of vocational training (IEK) & 18.8 & 9.2 \\
\hline Higher Technological Institution (TEI/KATEE) & 2.7 & 9.9 \\
\hline University (AEI) & 2.0 & 4.8 \\
\hline Post Graduate studies, Master / Doctorate & 0.5 & 0.1 \\
\hline Do not answer & & \\
\hline
\end{tabular}

Source: Goulas and Fotopoulos (2021).

In this sense, the solution here is surely not to "coerce" or "artificially redirect" students' trajectories into lower levels of qualifications and non-formal forms of education; not even to force students out of higher education institutions or incite them to pursue vocational training, without this being dictated by the real needs of production and the labour market. Initial vocational training obviously provides distinct and useful services (Fotopoulos, 2013). 
However, it needs to be weighed and not derived from practices that do away with the pursuit of high-level innovation and intensity qualifications that could be key drivers for the competitiveness of the Greek economy. A key strategy is required including enhancing, strengthening, and reinforcing the qualifications and skills offered by universities, to facilitate graduates' access to professional roles with wages and salaries based on their qualifications on the scale of the National and European Qualifications Framework. The strategy can only be associated with increased funding, infrastructure upgrading, strengthening human and scientific capacity, developing modern schemes of apprenticeship, strengthening employment offices, and linking universities to production and professional fields - to which the studies they provide-correspond.

As it follows from the foregoing the Greek family has constantly invested in education with all the resources at its disposal. The picture of private spending on education in our country confirms the long-term commitment of households to education, since the main principle following the regime change requiring "free education" has been irreversibly affected by the rise of "shadow education", which is substantiated by the exceptionally high private expenditure on education goods and services. Despite the multiple obstacles, modern Greek families are obstinately sticking to the value of education by providing, with a view to having their members effectively integrated into the labour market on the best possible terms (Katartzi, 2017). Even though they know that this investment is no longer as rewarding as it used to be, they continue to recognise education as one of the key mechanisms for upward occupational and social mobility. Besides, it is not by chance that our country ranks 1 st in the EU in terms of the percentage of students in higher education (undergraduate students) and $3 \mathrm{rd}$ in terms of the percentage of $\mathrm{PhD}$ students compared to the rest of EU-28 Member States.

\section{Teaching Staff: Elderly, Qualified But Poorly Paid}

It is important to mention the human capital potential in the field of education (Becker, 2009). That is because the demand for better and more accessible education does not only concern families. The educational qualifications of the teaching staff at all levels of education appear to be higher than the European average, since Greek teachers have a high-level postgraduate qualification, advanced linguistic skills, computer skills, etc. This consideration demonstrates the high level of mobility and vigilance they display, at a time when they are obviously fully aware of the fact that the teaching profession is competitive, demanding and closely related to lifelong learning culture.

According to the data in a Report carried out by KANEP in 2017, the proportion of teachers with additional academic qualifications represents (marginally) a comparative advantage of the public education sector, since the improved academic qualifications are a considerable asset -along with the professional experience-for claiming a position in the administrative/scientific hierarchy of education. More specifically, the highest value for that indicator among the different levels of primary and secondary education is recorded in the general lyceum, with $43.0 \%$ of the teaching staff possessing additional academic qualifications. In descending order, the values for that indicator are as follows: the vocational lyceum \& the technical vocational education school (EPAS apprenticeships) within the area 
of competence of the Ministry of Education and Religious Affairs with $42.2 \%$, the gymnasium with $39.1 \%$, the nursery school with $27.4 \%$ and the primary school with $27.3 \%$. This element should be deployed and enhanced by the state, with a view to developing training and lifelong learning within schools, providing incentives, opportunities, and the media through which the teaching staff can focus on their continuing professional development and scientific upgrading (KANEP, 2017).

At the same time, however, an ageing teaching force (but also an ageing laboratory and other administrative staff) is recorded at all levels of education to a significant extent, an event marking a standstill in respect of human resources development and mobility. In particular, the different levels of primary and secondary education vary in respect of the average age of the teaching staff. According to the 2017 Report, the highest average age of the teaching staff is recorded in the general lyceum (47.5 years old) and in descending order of average value the gymnasium (46.3 years old), the vocational lyceum \& the technical vocational education school (EPAS apprenticeships) within the area of competence of the Ministry of Education and Religious Affairs (45.7 years old) follow. Based on the 2017 Report on education, this ageing teaching force is the second equally major problem along with the issue of infrastructure inadequacy and low quality in Greek education (KANEP, 2017). In particular, the ageing teaching staff issue is associated with the extremely low inflows of young teachers but also with older teachers' tendency to retain for long-term careers in the classroom. It is worth noting that even when ASEP (Supreme Council for Selection of Personnel) examinations were held for teacher recruitment, it was mainly older teachers - combining many years of service as supply teachers along with their rank in the pass lists-who were being hired. The same applies today as through the candidates' rank in the pass lists based on their qualifications, older teachers - with a longer service as supply teachers in conjunction with points gained for the additional academic qualifications they have acquired during their professional career - are hired. Considering those who stay in the profession longer, either because the retirement age has increased or because they do not want to leave education due to lower pensions, we understand how we end up with this high rate of ageing teaching force. In any case, however, it is critical for socially just and rational methods to be found for the inflow of younger staff in order to renew and strengthen the dynamics of the teaching profession.

As regards the remuneration of teaching staff, an extremely low position is registered at European Union level, a finding that needs to be taken directly into account in the education policy framing. This is because-besides the fact that the role of human resources in education is devalued - the perspective of our education system is undermined if the educational staff is not renewed and its contribution to the country's growth perspective is not broadly recognised. Certainly, the human resources need to be reinforced and, most importantly, strengthened both symbolically and practically, so that its full potential can be unleashed as a factor of development and social cohesion in the field of education. 
Table 11. Annual gross statutory starting salaries (EUR) for full-time, fully qualified teachers in public schools, 2018/19

\begin{tabular}{|c|c|c|}
\hline Countries & Preprimary and primary teachers & Lower and upper secondary teachers \\
\hline Luxembourg & $67,391.0$ & $76,376.0$ \\
\hline Germany & $50,029.0$ & $56,848.0$ \\
\hline Denmark & $49,108.0$ & $51,603.0$ \\
\hline Netherlands & $35,600.0$ & $37,809.0$ \\
\hline Sweden & $35,584.0$ & $37,513.0$ \\
\hline Belgium & $33,034.0$ & $37,135.0$ \\
\hline Austria & $37,332.0$ & $36,553.0$ \\
\hline Finland & $30,912.0$ & $36,326.0$ \\
\hline Ireland & $36,318.0$ & $36,318.0$ \\
\hline Spain & $29,918.0$ & $33,392.0$ \\
\hline United Kingdom & $28,417.0$ & $28,417.0$ \\
\hline France & $26,329.0$ & $27,709.0$ \\
\hline Italy & $23,993.0$ & $25,829.0$ \\
\hline Malta & $21,602.0$ & $23,716.0$ \\
\hline Portugal & $22,310.0$ & $22,310.0$ \\
\hline Slovenia & $18,658.0$ & $18,658.0$ \\
\hline Estonia & $14,600.0$ & $14,600.0$ \\
\hline Lithuania & $12,104.0$ & $14,304.0$ \\
\hline Croatia & $13,547.0$ & $13,547.0$ \\
\hline Greece & $13,104.0$ & $13,104.0$ \\
\hline Czechia & $12,458.0$ & $12,902.0$ \\
\hline Slovakia & $8,363.0$ & $8,832.0$ \\
\hline Latvia & $8,520.0$ & $8,520.0$ \\
\hline Romania & $8,413.0$ & $8,413.0$ \\
\hline Poland & $7,226.0$ & $7,226.0$ \\
\hline Hungary & $7,193.0$ & $7,193.0$ \\
\hline Bulgaria & $5,161.0$ & $5,161.0$ \\
\hline
\end{tabular}

Note. Countries are ranked by the secondary teachers' salary.

Source: European Commission/EACEA/Eurydice, 2020. Teachers' and School Heads' Salaries and Allowances in Europe-2018/19. Eurydice Facts and Figures. Luxembourg: Publications Office of the European Union (INE/GSEE \& KANEP/GSEE, 2020). 


\section{Discussion and Conclusion}

In conclusion, the Annual Reports, and current data at European level on education confirm the connection of education with the wider social, economic, and cultural context of the country. The findings substantially ratify the correlation of educational reality with the broader weaknesses of the society, demonstrating an extremely disturbing situation in relation to the European reference framework, but also in relation to a general failure to change weaknesses that have had negative effects for decades.

The reduction of public spending on education, "shadow education", the spread of privatization (Kamarianos et al., 2020) and the unemployment of our graduates are obvious and perennial problems that need to be addressed in a rational and, mainly, politically innovative manner so that they can be tackled effectively. Confidence in the human resources of education, their pedagogical, scientific, and financial assistance, the protection of their rights and the understanding of their mission will contribute considerably to redressing failures, giving an impetus for modernisation and future development of Greek educational system. Undoubtedly, initiatives and practices, such as a strong political will, the wide, frank and sound social agreements, the composition of forces, as well as the formulation of a socially acceptable national strategy for education can operate supportively towards the protection of the public and social nature of education, the reduction of educational and social disparities, the development and social cohesion. At the same time, they will make a definite contribution to redefining a shared vision that will give hope and perspective to young people, who are anxious about their future and dream of a better life in Greece.

\section{References}

Allegro, R., \& Giambalvo, O. (2020). About Overeducation and Mismatching. University Performance before and during Economic Crises (pp. 3-6). Springer, Cham. https://doi.org/ 10.1007/978-3-030-36142-6_2

Becker, G. S. (1993). Human capital: A theoretical and empirical analysis, with special reference to education (3rd ed.). Chicago \& London: University of Chicago Press. https://doi.org/10.7208/chicago/9780226041223.001.0001

Bray, T. M. (2011). The challenge of shadow education: Private tutoring and its implications for policy makers in the European Union. European Commission.

Chalari, M. (2017). Crisis, austerity, and its impact on education in Europe and Greece. Educate, 16(1), 15-24.

Docquier, F., \& Rapoport, H. (2012). Globalization, brain drain, and development. Journal of Economic Literature, 50(3), 681-730. https://doi.org/10.1257/jel.50.3.681

European Commission/EACEA/Eurydice. (2020). Teachers' and School Heads' Salaries and Allowances in Europe-2018/19. Eurydice Facts and Figures. Luxembourg: Publications Office of the European Union.

Eurostat-General Government Expenditure by Function (COFOG) [gov_10a_exp] 
(extracted on $06 / 04 / 2021$ ).

Eurostat - Youth long-term unemployment rate (12 months or longer) by sex and age [yth_empl_120] (extracted on 08/04/2021).

Eurostat-Pupils and students enrolled by education level, sex and field of education [educ_uoe_enra03] (extracted on 06/04/2021).

Eurostat - Unemployment rates by sex, age and educational attainment level (\%) [1fsa_urgaed] (extracted on 06/04/2021).

Fotopoulos, N. (2013). VET, Employment, Education Policy. Athens: KANEP-GSEE.

Goulas, C., \& Fotopoulos, N. (2021). Vocational Training and Employment, Empirical and comparative investigation of the conditions of transition of I.E.K. graduates to employment. Athens: KANEP-GSEE.

Hanushek, E. A., \& Kain, J. F. (1972). On the value of equality of educational opportunity as a guide to public policy. In Fr. Mosteller \& D. Moynihan (Eds.), On equality of educational opportunity (pp.116-145). New York: Random House.

INE/GSEE \& KANEP/GSEE. (2020). The transition of the greek economy to a new model of development. Athens: INE/GSEE. Retrieved from https://www.inegsee.gr/ekdosi/i-metavasitis-ellinikis-ikonomias-se-ena-neo-ypodigma-anaptyxis-mia-enallaktiki-protasi-stin-ekthesi-p issaridi

John, P. (2013). Analyzing public policy. Routledge, UK. https://doi.org/10.4324/97802031 36218

Kamarianos, G., Kyridis, A., Fotopoulos, N., \& Chalkiotis, D. (2019). The public school in Greece, Facets and Trends of increasing Privatization. Athens: DOE, OLME, Education International.

KANEP. (2017). Annual report on education 2016: Key Indicators on Education: the Greek primary and secondary education-Part two. Athens: Centre for Education Policy Development of GSEE (KANEP/GSEE). Retrieved from https:/www.kanep-gsee.gr/ wp-content/uploads/2017/04/ETEKTH2016.pdf

KANEP. (2019). Key indicators on Education 2019-2020, Education and Employment in Greece-European frame of reference (2001-2018), Special research report-Updated indicators. Athens: Centre for Education Policy Development of GSEE (KANEP/GSEE). Retrieved from https:/www.kanep-gsee.gr/wp-content/uploads/2019/09/kanep-ekthesi0920 19.pdf

KANEP. (2020). Annual report on education 2019-2020: Key Indicators on Education: Education and Employment-Part one: European frame of reference (2001-2018). Athens: Centre for Education Policy Development of GSEE (KANEP/GSEE). Retrieved from https://kanep-gsee.gr/\%CE\%95\%CE\%A4\%CE\%95\%CE\%9A\%CE\%98\%202019-20.pdf

Kassotakis, M., \& Verdis, A. (2013). Shadow education in Greece: Characteristics, 
consequences, and eradication efforts. In M. Bray, A. Mazawi, \& Sultana, R. (Eds.), Private tutoring across the Mediterranean (pp. 93-113). Brill Sense. https://doi.org/10.1007/ 978-94-6209-237-2_6

Katartzi, E. (2017). Youth, family, and education: Exploring the Greek case of parentocracy. International Studies in Sociology of Education, 26(3), 310-325. https://doi.org/10.1080/ 09620214.2017.1300067

Labrianidis, L., \& Vogiatzis, N. (2013). Highly skilled migration: what differentiates the 'brains' who are drained from those who return in the case of Greece? Population, Space and Place, 19(5), 472-486. https://doi.org/10.1002/psp.1726

Liagouras, G., Protogerou, A., \& Caloghirou, Y. (2003). Exploring mismatches between higher education and the labour market in Greece. European Journal of Education, 38(4), 413-426. https://doi.org/10.1111/j.0141-8211.2003.00158.x

Mills, C., \& Gale, T. (2007). Researching social inequalities in education: Towards a Bourdieuian methodology. International Journal of Qualitative Studies in Education, 20(4), 433-447. https://doi.org/10.1080/09518390601176523

Tsakloglou, P., \& Cholezas, I. (2005). Education and inequality in Greece. Discussion Paper Series, IZA DP No. 1582. Bonn: Institute for the Study of Labour. Retrieved April 10, 2015 from http://ftp.iza.org/dp1582.pdf

\section{Copyright Disclaimer}

Copyright for this article is retained by the author(s), with first publication rights granted to the journal.

This is an open-access article distributed under the terms and conditions of the Creative Commons Attribution license (http://creativecommons.org/licenses/by/3.0/). 